\title{
Refinements to the burning strategy in the Etosha National Park, Namibia
}

\section{W.P. DU PLESSIS}

Du Plessis, W.P. 1997. Refinements to the burning strategy in the Etosha National Park, Namibia. Koedoe 40(1): 63-76. Pretoria. ISSN 0075-6458.

\begin{abstract}
Until 1980, official policy forbade intentional veld-burning within the boundaries of the Etosha National Park. It was only in 1981 that fire was recognised by management and research as playing a fundamental role in the development and maintenance of the current vegetation communities. An objective approach to intentional veld-burning is presented simulating the incidence of lightning fires, and the subjectivity in choosing areas to burn is reduced. The selection of areas to burn depends on the mean seasonal rainfall in each burning block, the time since it last burnt and the accumulation of herbaceous fuel. Additional factors considered are the moribundness in grasses, the game pressure and the cover of green vegetation derived from satellite data.
\end{abstract}

Key words: burning strategy, disc pasture meter, Etosha National Park, NDVI, NOAA AVHRR.

W.P. du Plessis, Etosha Ecological Institute, Ministry of Environment \& Tourism, P.O. Okaukuejo, via Outjo, Namibia.

\section{Introduction}

The Etosha National Park (Etosha) was proclaimed as a wildlife reserve in 1907, comprising an area of $99526 \mathrm{~km}^{2}$. This area was reduced in 1958 and 1970 resulting in the present day Etosha with co-ordinates centered at $19^{\circ} \mathrm{S} ; 16^{\circ} \mathrm{E}$ (Berry 1980) and comprising an area of $22915 \mathrm{~km}^{2}$ (this publication). Almost all of Etosha may be described as arid to semi-arid savanna $(250-500 \mathrm{~mm}$ average annual rainfall) with a highly variable and erratic rainfall pattern (Engert 1992).

It has been proposed that the single most important management objective for Etosha should be "the maintenance and in special cases the increase of biotic diversity". The procedures for achieving this objective is described in the Masterplan for the Etosha National Park (Nott et al. 1985) which, although not officially approved, still expresses the accepted guidelines for park management. The burning strategy proposed in this paper is believed to be a positive management action towards the achievement of the aforementioned primary objective. The need to establish a definite set of park man- agement actions and to regularly monitor the effectiveness of such actions is both a management and research priority.

Until 1980, official policy forbade controlled burning within the boundaries of Etosha. All anthropogenic and lightning fires were either extinguished or contained within the smallest possible area. This led to the construction of firebreaks and the development of an experienced fire fighting team. It was only in 1981 that fire was recognised by management and research as playing a fundamental role in the development and maintenance of the current vegetation communities. Fire was then finally acknowledged to be an efficient means for the removal of moribund grass material, controlling bush encroachment, recycling nutrients and manipulating game movements (Scholes \& Walker 1993). Initially, areas to be burnt each year were chosen subjectively. This subjectivity, compounded by high staff turnover, led to obvious discontinuity and inconsistencies in the selection of areas to be burnt.

Siegfried (1980) investigated the natural incidence of fires in Etosha. His argument was that the optimal practice for the manage- 


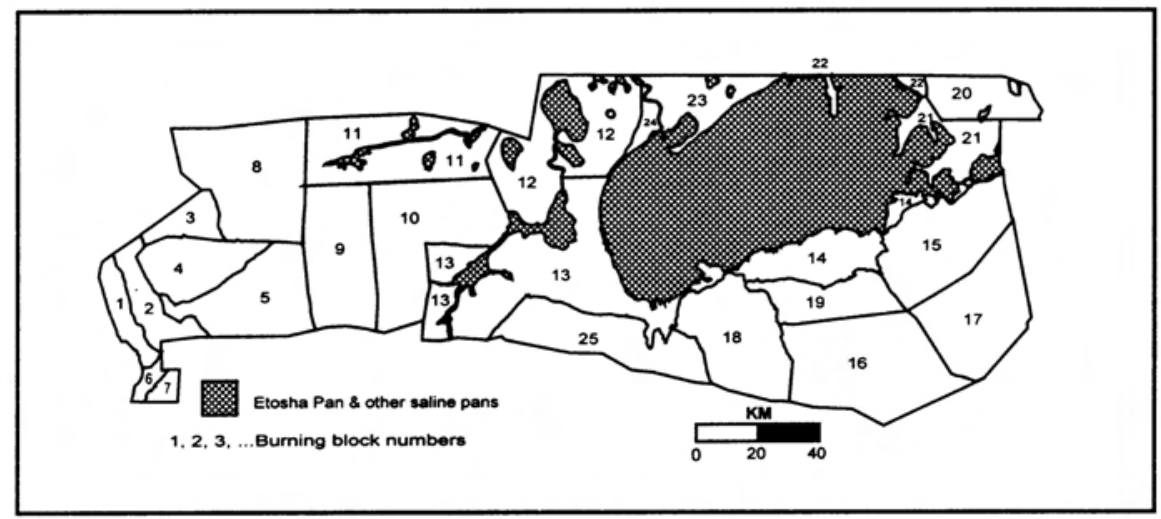

Fig. 1. Burning blocks in the Etosha National Park.

ment of nature reserves are often those which most closely imitate natural processes. Hence burning regimes might be applied advantageously if they are modeled on the natural incidence of fire.

Siegfried (1980) found that $54 \%$ to $73 \%$ of all fires between 1970 and 1979 were caused by lightning. Seventy eight percent of all fires occurred from September to December. During 1975 the rainfall was double the normal annual rainfall which resulted in the highest incidence of fires during the period 1970 to 1979. The above-normal rainfall resulted in the production of high grass fuel loads and therefore high fire frequencies. Siegfried (1980) suggested that Etosha can be expected to have very high above-normal rainfall approximately every 11 years which will result in most of the park being burnt. The spatial incidence of fires was such that virtually all vegetated areas in Etosha burnt at least once between 1970 and 1979.

This paper explains the burning policy currently used in the Etosha National Park which is based on recommendations made by Nott et al. 1985 and a publication by Stander et al. 1993. The old and current strategy aims at simulating the expected incidence of fire caused by lightning. This approach is strongly recommended for the drier regions of southern Africa (Gertenbach \& Potgieter 1979). Certain refinements to the burning policy are proposed in this paper based on field observations and research results additionally obtained during the period 1988 to 1996.

\section{Rainfall measurements as the basis for the burning strategy in Etosha}

The old and current burning strategy are primarily based on rainfall measurements of field rain gauges in Etosha (Nott et al. 1985, Stander et al. 1993). A description of the methodology for measuring rainfall is repeated in this paper because the published burning strategy of Stander et al. (1993) excluded some details which are considered to be of importance for a comprehensive understanding of the burning strategy currently used in Etosha.

For management purposes, Etosha has been divided into five major zones. These zones have been further divided into burning blocks (Fig. 1) based on relative homogenous vegetation communities (Fig. 2) (adapted from Le Roux et al. 1988) and edaphic and topographic features using existing firebreaks and tourist roads (Fig. 3).

Field rain gauges were erected throughout Etosha in 1983. These rain gauges were placed at water points, official buildings in rest camps, field horse camps, road intersections and other easily identifiable and/or protected locations. The size of Etosha, the 


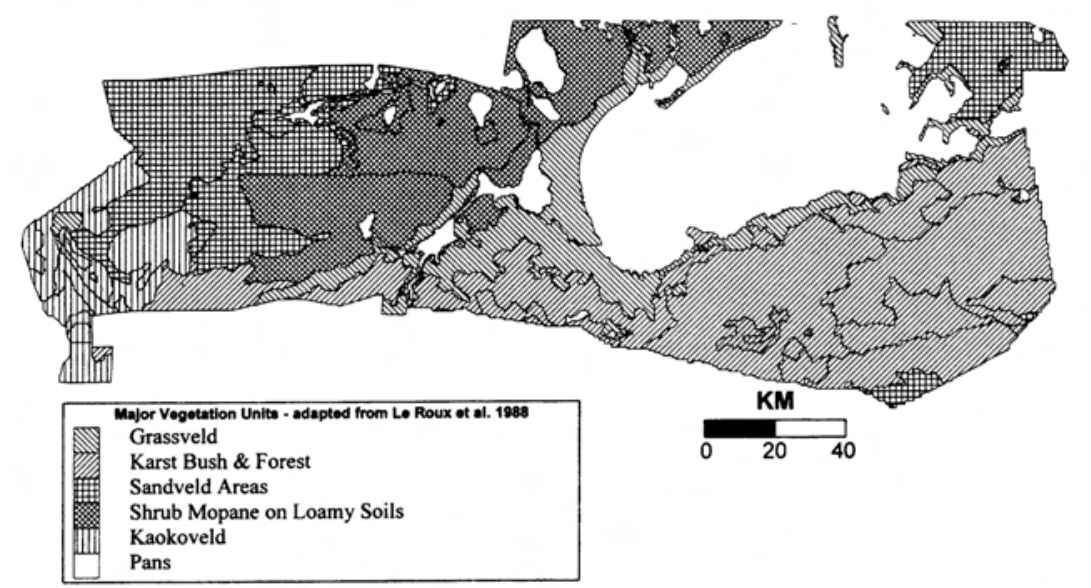

Fig. 2. Major vegetation units in the Etosha National Park, adapted from Le Roux et al. 1988.

number of rain gauges to be checked and limited staff, made regular measurements of rainfall impossible. Many of the field rain gauges were also inaccessible during the rainy season. Rain gauges were, therefore, constructed to be able to store an entire season's rainfall (e.g. from July 1983 to June 1984). To achieve this, standard aluminum BTS rain gauges with a funnel (the funnel's top is slightly larger that the diameter of the rain gauge) were fitted into the top of galvanised cylindrical containers of one meter in length and $110 \mathrm{~mm}$ in diameter. In 1996, damaged galvanised rain gauges were replaced with UV-resistant one-meter PVC pipes of $110 \mathrm{~mm}$ in diameter with an internal funnel. These PVC gauges will, in future, replace all galvanised gauges. They are longlasting and much cheaper to replace when damaged.

Initially 136 rain gauges were erected throughout Etosha. This number was increased to 156 gauges in 1991, and 168 gauges in 1996 (Fig. 4). Optimal sampling

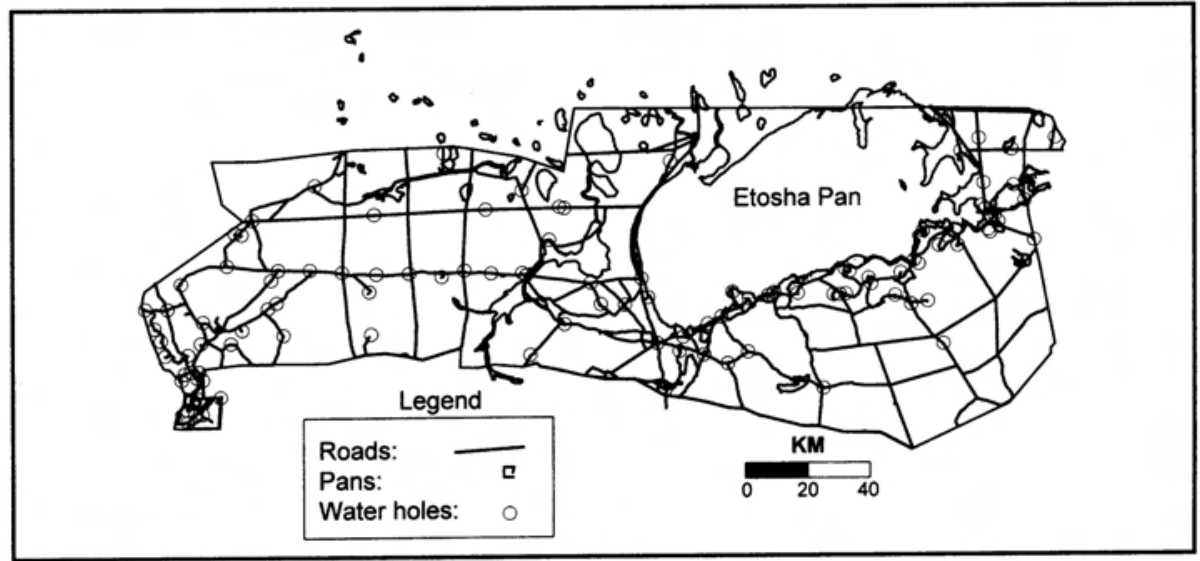

Fig. 3. A map of the Etosha National Park showing saline depressions and infrastructure like roads and water holes. 


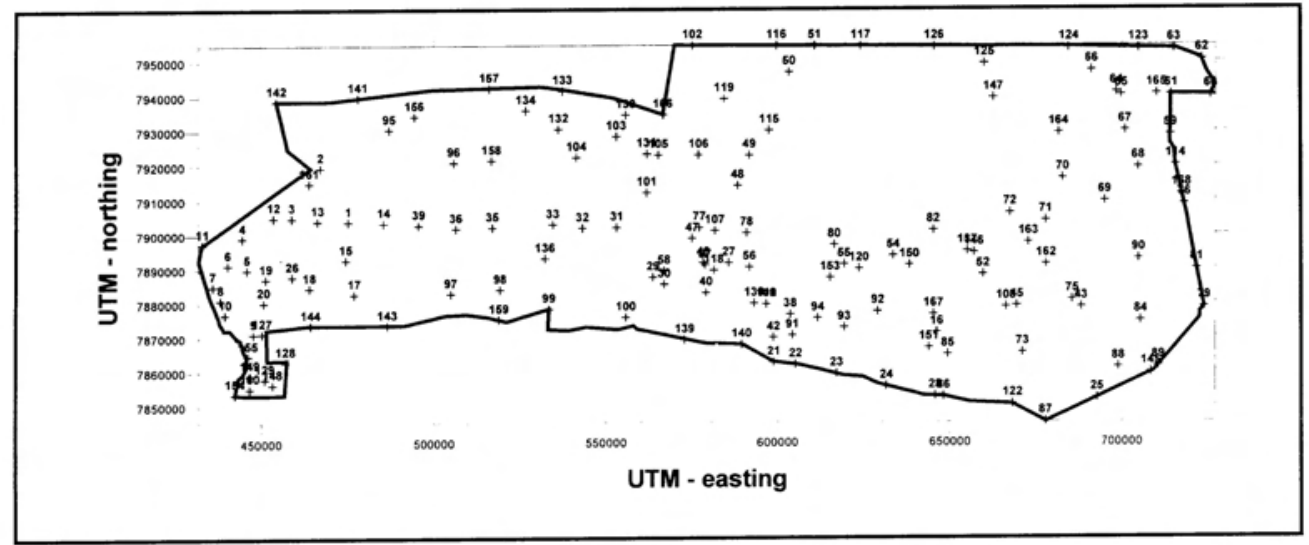

Fig. 4. Positions of field rain gauges in the Etosha National Park determined with a GPS.

intensity, using the running mean (MuellerDombois \& Ellenberg 1974), indicated that approximately 136 rain gauges should be adequate (Table 1). However, all reliable rainfall data are used every year.

Various fluids, with specific gravity lower than water-including paraffin, brake fluid, vegetable oil and SAE 30 motor oil-were tested for their effectiveness in preventing evaporation of the rain water collected in the one-meter gauges. Evaporation was significant in test gauges containing paraffin, brake fluid and vegetable oil, but was not evident when using SAE 30 motor oil. Thus $15 \mathrm{~mm}$ of this motor oil was used in all gauges, and subtracted from the yearly total measured. During 1984 to 1995 , an average of $24.6 \%$ of rain gauges were either damaged by animals, leaking, or lost. This emphasises that all available rain gauge data should be used each year in calculating the mean rainfall of areas.

Field rain gauges were calibrated against a calibrated rain gauge at the first order weather station at Okaukuejo in 1983. Rainfall totals were accordingly multiplied by a factor of 0.80 for galvanised gauges and 1.0 for PVC gauges (only used from 1996), after subtracting $15 \mathrm{~mm}$ from each gauge representing the motor oil. Total annual rainfall was measured in July by inserting a metal ruler into the field rain gauges. The location of each field rain gauge was identified by placing a $3.3 \mathrm{~km}$ grid overlay $(96 \times 32$ data matrix) over the map of Etosha. In 1996, the positions of all gauges (Fig. 4) were determined accurately using a GARMIN 100 Global Positioning System (GPS).

The mean rainfall for each burning block was calculated using rainfall totals of all the gauges located in each block. In addition, most burning blocks shared at least some rain gauges' data because the gauges were often placed on the roads between two blocks. Each burning block's rainfall means were compared to the 20-year rainfall means of weather stations at Namutoni, Halali, Okaukuejo, Ombika and Otjovasandu (Table 2 ). These 20-year rainfall means are considered to be adequate for establishing a statistically reliable rainfall mean (Statistica for

Table 1

Determining the optimum sampling intensity using the running mean of field rain gauges in Etosha. $S E M=$ Standard error of the mean $(S D / n), S E M / M$ = Running mean error term (SEM/Rainfall mean)

\begin{tabular}{lllll}
\hline $\begin{array}{l}\text { Sample } \\
\text { size }(\mathrm{n})\end{array}$ & $\begin{array}{c}\text { Rainfall } \\
\text { mean }\end{array}$ & SD & SEM & SEM/M \\
\hline 53 & 340 & 202.9 & 3.829 & 0.011 \\
79 & 327 & 175.4 & 2.220 & 0.007 \\
103 & 321 & 154.1 & 1.497 & 0.005 \\
114 & 329 & 152.0 & 1.334 & 0.004 \\
136 & 328 & 135.8 & 0.998 & 0.003 \\
156 & 326 & 120.2 & 0.771 & 0.002 \\
\hline
\end{tabular}


Table 2

Comparison of burning blocks with 20 year rainfall means at single and combined groups of weather stations in Etosha

\begin{tabular}{lcc}
\hline Weather stations & $\begin{array}{c}\text { Associated burning } \\
\text { block number }\end{array}$ & $\begin{array}{c}\text { Mean rainfall } \\
\text { between 1975 \& 1995 }\end{array}$ \\
\hline Otjovasandu & $1-9$ & 278 \\
Okaukuejo & $10-13+24$ & 329 \\
(Halali+Namutoni)/2 & $14+22$ & 402 \\
Halali & $16+19$ & 374 \\
Namutoni & $15+17+20+21$ & 430 \\
(Halali+Okaukuejo)/2 & 23 & 352 \\
(Okaukuejo+Ombika) $/ 2$ & $18+25$ & 356 \\
\hline
\end{tabular}

Windows version 5.01 software package). At least part of a cycle of above and below average rainfall is included when using a 20-year rainfall mean (Lindeque 1991, Engert 1992).

\section{Refinements and additions included in the current burning strategy}

\section{Determining the fuel load of grasses using a} disc pasture meter

The disc pasture meter (DPM) was calibrated in Etosha (Kannenberg 1992) for an objective and quick determination of the standing crop of grass-and hence the grass fuel load of selected blocks--before controlled burns were implemented according to the procedures proposed by Trollope \& Potgieter (1986). The amount of fuel available is critical since Trollope \& Potgieter (1985) found that a fire will not readily spread if the fuel load is less than $2000 \mathrm{~kg} / \mathrm{ha}$. This was confirmed by field observations and measure- ments in Etosha. Additional data were added in 1993 (by the author) to the calibration of the DPM (Fig. 5), and a coefficient of determination $\left(\mathrm{r}^{2}\right)$ of 0.7823 indicated a strong positive relationship between disc settling height and herbaceous fuel load. The DPM has been in use since 1992 .

\section{Moribundness of grasses}

High levels of moribundness and necromass in the grass layer lower the productivity of palatable grass species to grazers and will eventually result in a decrease in the density of grass tufts (Scholes \& Walker 1993). Trollope et al. (1996) indicated that grass only becomes moribund at a fuel load of approximately $4000 \mathrm{~kg} / \mathrm{ha}$ in the Kruger National Park, which is the stage that veld should be considered for burning in order to maintain the vigour of the grass sward. However, grass, especially perennial species, may become moribund at fuel loads that are

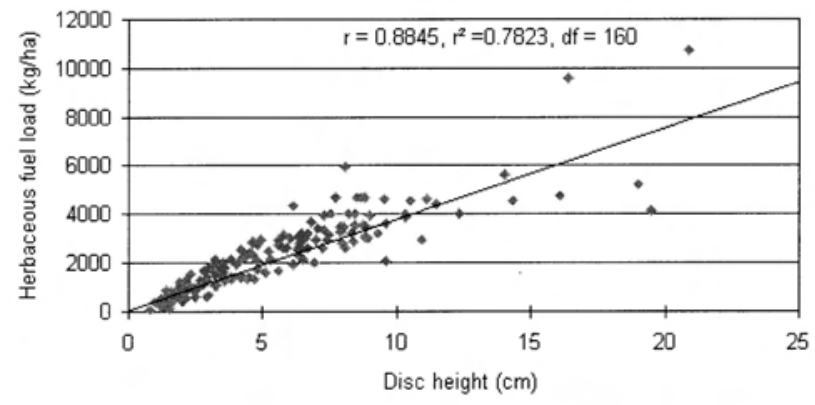

Fig. 5. Relationship between herbaceous fuel loads (independent variable) and disc height (dependent variable) recorded with a disc pasture meter (DPM) in the Etosha National Park. 
lower than $2000 \mathrm{~kg} / \mathrm{ha}$ in Etosha. In an arid environment like Etosha, where the decomposing process is much slower than in areas with higher rainfall, annual and perennial standing dry grass become moribund if an area receives rain but was not highly utilised before the rain. Field observations have shown that a pure stand of the annual grass Schmidtia kalihariensis, with a standing crop of approximately $1000 \mathrm{~kg} / \mathrm{ha}$, became about $70 \%$ moribund within two months after the first rains of the following rainy season.

The degree of moribundness of grasses (especially perennials) in selected blocks are subjectively estimated to the nearest five percent shortly before burning a selected area. A high percentage of moribundness (>50\%) strengthens the decision to burn selected blocks. A low percentage of moribundness $(<20 \%)$ lowers the priority to burn selected blocks. Assessing the moribundness of the grass layer as a parameter in influencing the decision to burn has been incorporated into the burning strategy in 1992 .

\section{Game pressure}

Game pressure, inside and around selected blocks to be burnt, is assessed subjectively shortly before burns by driving around or flying over the selected blocks. High game pressure in selected blocks lowers the priority to burn such blocks, especially if adjacent unselected blocks have a low standing crop of grasses. This is to prevent potential shortages in food, especially to grazers, because grasses often do not start to grow for up to four months after an early burn. This parameter has been incorporated in the burning strategy in 1992.

\section{Changing the layout of burning blocks}

The position of the initial burning blocks (Stander et al. 1993) were in some cases modified to correspond more accurately to vegetation units identified by Le Roux et al. (1988), or for practical considerations related to existing roads (Fig. 1). For example, the old block 18 (Stander et al. 1993) was divid- ed into two blocks, block 18 and 25 , because it was spread over too large a rainfall gradient from west to east. Blocks 14, 20 and 22 were modified for practical considerations regarding the presence of roads, and to correspond closer to vegetation units.

Another alteration that will be considered in the near future is to incorporate the far western section of block 13 (west of M'Bari water hole) into block 10 . The reason is that this area is "shrub mopane veld" like block 10 , and not "sweet grassveld on lime" like the rest of block 13, and has not burnt since 1976 which has resulted in a higher density of shrubs and trees, and a much higher percentage of moribund grass compared to the adjacent block 10. The sweet grassveld on lime (Le Roux et al. 1988) areas of the current block 13 may additionally need to be separated further into a western section and eastern section. The reason is that the eastern section nearly always has a high game pressure which reduces the fuel load and the area will not easily qualify for burning. This negatively affects the western section which has generally a lower game pressure and sometimes enough grass available to burn effectively.

\section{Comparison of blocks selected for burning with their average NDVI values}

A satellite image receiving and processing system, developed by Bradfield University (Stephenson 1991) and donated by the Overseas Development Administration (ODA) through the Natural Resources Institute in England, was placed at Okaukuejo and has been operational since January 1993. Images from the AVHRR (Advanced Very High Resolution Radiometer) sensor aboard the American NOAA (National Oceanic and Atmospheric Administration) series of satellites are captured on a daily basis for the entire country.

Day-time images are processed into Normalised Difference Vegetation Index (NDVI) products according to the equation:

$$
\text { NDVI }=\begin{aligned}
& \operatorname{ch} 2-\operatorname{ch} 1 \\
& \operatorname{ch} 2+\operatorname{ch} 1
\end{aligned}
$$


where ch1 and ch2 are the red and nearinfrared bidirectional reflectances respectively (expressed as a percentage). Channel 1 $\& 2$ have spectral reflectances respectively between 0.58 to 0.68 and 0.73 to $1.10 \mu \mathrm{m}$ (Lillesand \& Kieffer 1994). The NDVI equation produces values in the range of -1.0 to 1.0. Typically, small but positive NDVI values of 0.01 to 0.15 correspond to bare soils, and values from of 0.16 to 0.6 indicate increasing cover of green vegetation.

NDVI images of the entire country are geometrically corrected to a standard projection window to give uniformity of pixel positions across the multi-date images. The corrected images are then combined over contiguous 10 day periods ( 3 dekads per month) using a process known as maximum value compositing. This yields a single resultant image for each dekad, which gives the maximum NDVI value observed at each pixel position for all the images assessed during the dekad. Maximum value compositing is again used to combine the dekadal images over the main rainy season, for the period September to April. The resulting image is used as an indication of green biomass accumulated during the rainy season, and also indicates the maximum fuel load available during the commencing dry season. The average max- imum NDVI values for each burn block are next extracted using the Atlas GIS software. The map produced (Fig. 6) relates relatively well to the total rainfall derived from the field rain gauges within each block. This, and other unpublished research indicate that maximum NDVI (MAX NDVI) is a good indication of effective rainfall, and has been used since 1995 in conjunction with the rainfall figures to refine decisions on block burning. MAX NDVI may be used to identify errors in the rainfall data, for example, in Fig. 6 the average MAX NDVI is in the medium class, but the average rainfall (Fig. 7) for block 23 is in the very low class, which is most likely incorrect.

\section{Fire detection}

Between 1984 and 1996 the extent of controlled, anthropogenic and lightning fires occurring in Etosha were determined by flying over the burnt areas using a light aircraft whenever available. This approach was found to provide a quick, easy and accurate way of determining the extent and position of fires. It was preferred to using LANDSAT MSS \& TM satellite images which are very expensive and are available only every 12 to 18 days.

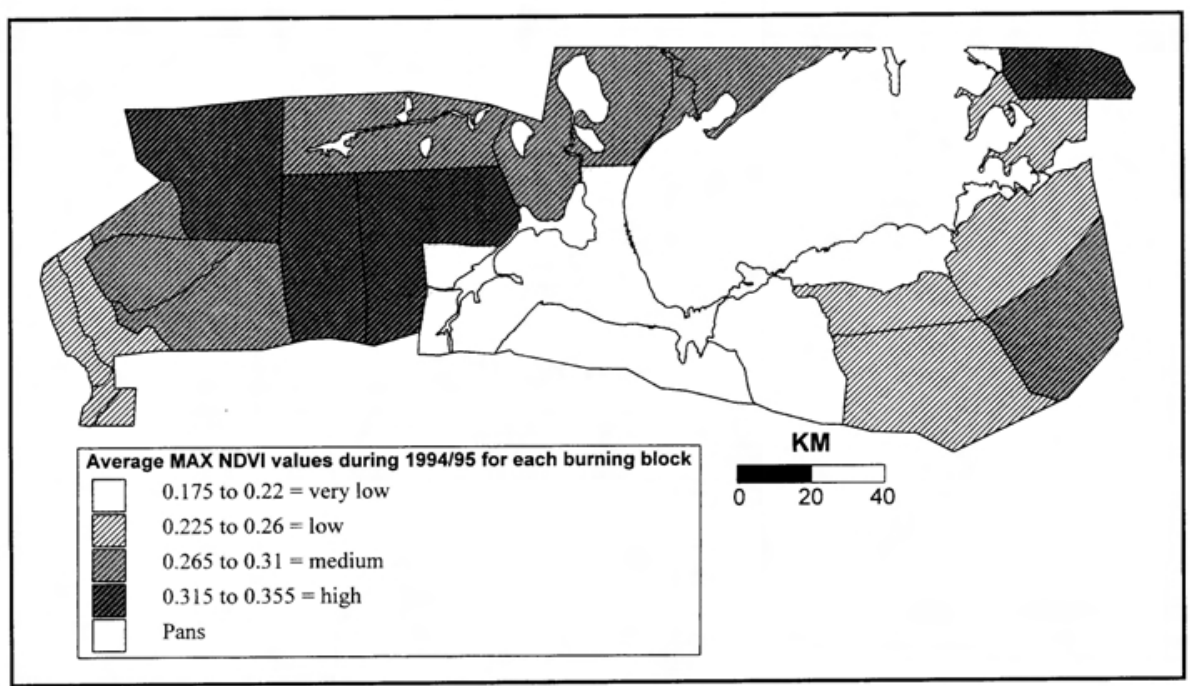

Fig. 6. The average maximum NDVI (MAX NDVI) values from the rainy season of 1994/95 recorded for each of the burning blocks in the Etosha National Park. 


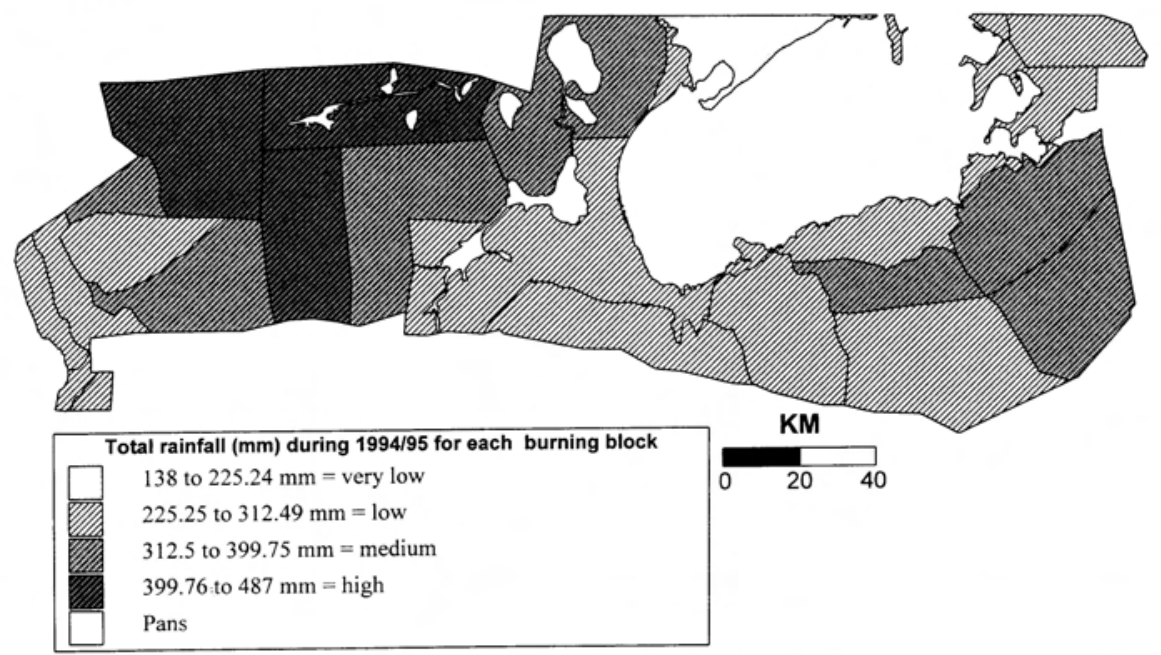

Fig. 7. Total rainfall (mm) during 1994/95 for each of the burning blocks in the Etosha National Park using field rain gauge data.

Images from channel 3 of the NOAA AVHRR system at the Institute, with an infrared spectral range between 3.5 to $3.93 \mu \mathrm{m}$ (Lillesand \& Kieffer 1994), are captured during the potential fire season between April to December, for the whole of Namibia, since 1994. These images are used in and outside of Etosha as a real-time, cost effective means for the synoptic daily monitoring of fires. The position and size of active fires can be determined and the extent of fire scars can be measured after a fire has been extinguished or died down. Fig. 8 is an example of a nighttime computer bitmap image from October

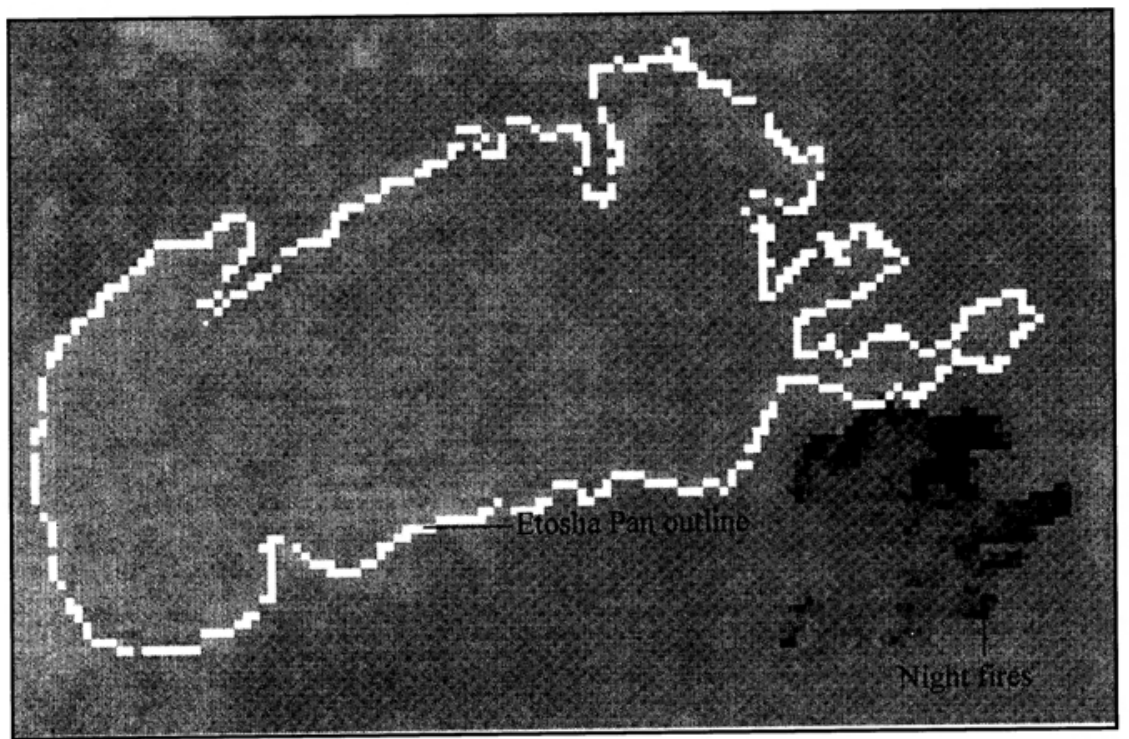

Fig. 8. Map of the position of fires detected at night during October 1994 with channel 3 of the NOAA AVHRR satellite receiving and processing system at the Etosha Ecological Institute. 


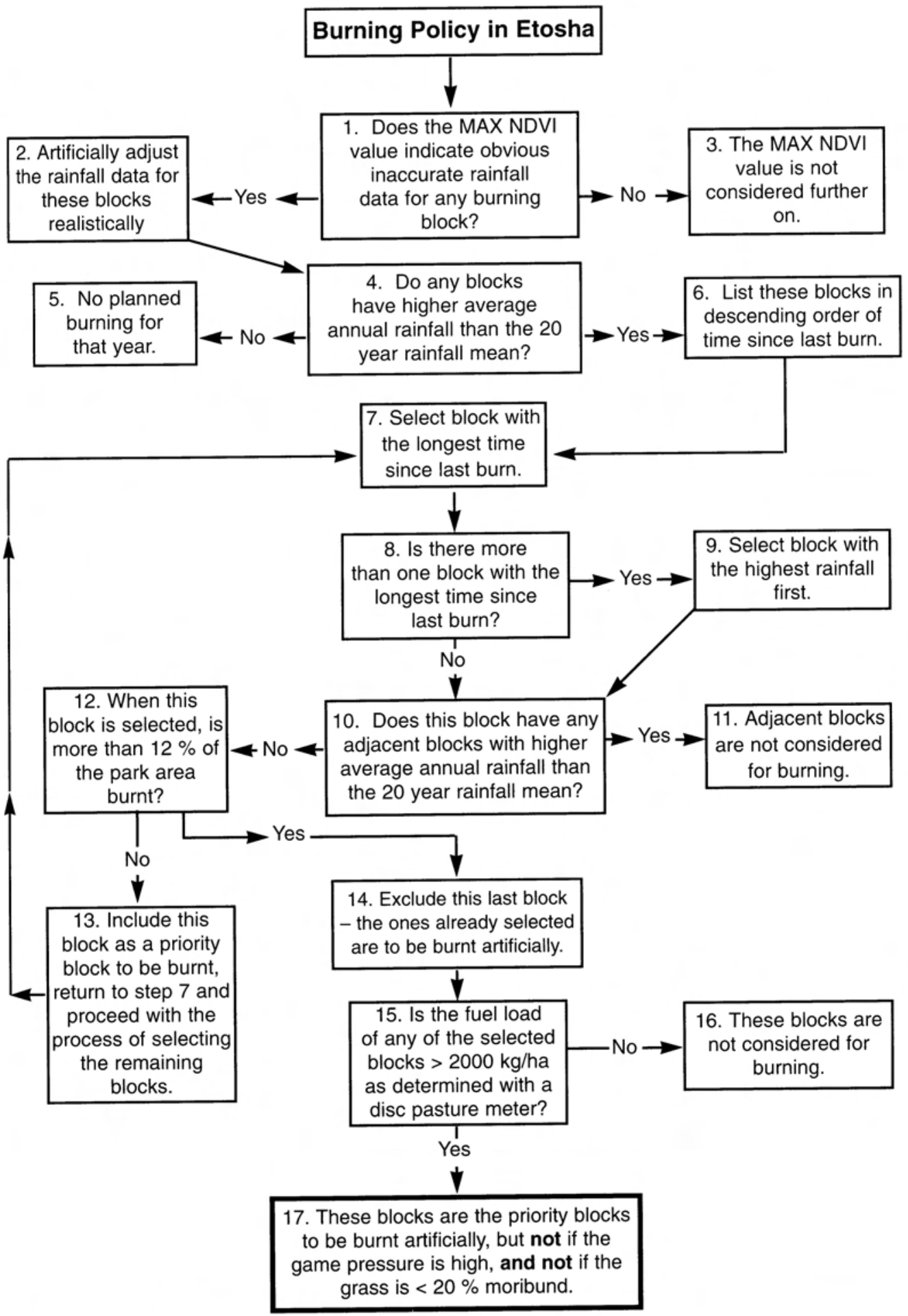

Fig. 9. Algorithm for annual priority block selection of controlled burns in the Etosha National Park. 
1994 of active fires detected south-east of the Etosha Pan, using Channel 3 of the NOAA AVHRR system.

\section{The current burning strategy in Etosha with the above refinements and additions incorporated}

The following approach is presented as an objective means of selecting burning blocks in Etosha. To simplify the explanation, refer to the algorithm in Fig. 9 at the same time.

The maximum NDVI value (MAX NDVI) for each burning block of the rainy season (Fig. 6) is evaluated and compared with the average rainfall (Fig. 7) for that block. If the average rainfall of any block is two or more classes lower or higher than the average MAX NDVI value of related blocks, the rainfall data are most likely inaccurate, and are artificially adjusted according to the level and direction of change indicated by the MAX NDVI values (step 1, 2 \& 3). These changes will result in a more accurate selection of priority blocks to be burnt.

If the average annual rainfall calculated for a burning block is lower than the 20-year rainfall mean at the chosen weather station (Table 2), it is not considered for burning that year (step 4 \& 5).

Blocks with rainfall higher than the 20-year rainfall mean are arranged in descending order of the time since the last burn (step 6), and the block with the longest period since the last burn is selected first (step 7). If more than one block has the longest time since the last burn, the block with the greatest amount of rainfall above the 20-year rainfall mean is selected first (step 8 \& 9).

Blocks, adjacent to the one just selected, are not considered for burning (step 10 \& 11). Adjoining blocks with only a short common boundary are not considered as being adjacent. These are blocks 1 and 6, 2 and 3,12 and 24,13 and 24, 14 and 21, 21 and 22, and 22 and 23.

Blocks are selected as priority blocks for burning until a maximum of $12 \%$ of the sur- face area of Etosha (excluding the Etosha Pan and other major saline depressions) has been attained (step 12, $13 \& 14)$. The selected blocks are not considered for burning if their fuel loads are less than $2000 \mathrm{~kg} / \mathrm{ha}$ as determined with a disc pasture meter (step $15 \& 16)$. Finally, the remaining selected blocks are not considered for burning if the game pressure is high and if the grass is less than $20 \%$ moribund (step 17).

Table 3 provides an indication of the size of each burning block and saline pans, expressed in square kilometers and in percentage of Etosha, as well as a list of the burning records for each of the blocks between 1968 and 1995 .

A block is considered to have burnt if more than half the block actually burnt. If, after a second attempt at burning the block, less than half of a block actually burnt, the block is considered "not" to have burnt.

\section{Lightning fires}

Other criteria, the most important of which are fires caused by lightning, form an integral part of the overall burning strategy. Fires caused by lightning are allowed to spread throughout a burning block irrespective of the amount of rain received that season. If such fires are prevented from spreading by internal non-firebreak roads, they are not induced to spread throughout the block. Lightning fires are contained within a block and are not allowed to spread to adjacent blocks. In exceptional drought years lightning fires will be limited to the smallest possible area. Accidental fires (anthropogenic fires) are always extinguished as soon as possible.

\section{Season of burning}

It is proposed for logistical reasons to initiate fires in September so that the fire team is able to complete planned burns and thereafter concentrate on those initiated by lightning, which require a quick response. The burning strategy demonstrated that areas selected to burn will pre-empt lightning 
Table 3

The size of burning blocks and pans in Etosha and the records of blocks burnt between 1968 \& 1995

\begin{tabular}{|c|c|c|c|c|c|c|c|c|c|c|c|}
\hline \multirow{2}{*}{$\begin{array}{l}\text { Block } \\
\text { number }\end{array}$} & \multirow{2}{*}{$\begin{array}{c}\begin{array}{c}\text { Block size } \\
\left(\mathrm{km}^{2}\right)\end{array} \\
234.2\end{array}$} & \multirow{2}{*}{$\begin{array}{c}\begin{array}{c}\text { Block size } \\
\text { (\% of park } \\
\text { excluding pans) }\end{array} \\
1.3\end{array}$} & \multicolumn{9}{|c|}{ Year of burning each block (19..) } \\
\hline & & & 70 & 75 & 80 & & & & & & \\
\hline 2 & 338.4 & 1.9 & 72 & 74 & 76 & & & & & & \\
\hline 3 & 235.8 & 1.3 & 76 & 77 & 90 & & & & & & \\
\hline 4 & 546.7 & 3.1 & 70 & 74 & 89 & 90 & & & & & \\
\hline 5 & 841.3 & 4.8 & 70 & 78 & 56 & & & & & & \\
\hline 6 & 68.5 & 0.4 & 75 & 80 & & & & & & & \\
\hline 7 & 75.3 & 0.4 & 70 & 75 & 77 & 78 & 91 & & & & \\
\hline 8 & 1219.7 & 6.9 & 71 & 78 & 80 & 85 & 89 & 91 & 93 & & \\
\hline 9 & 949.9 & 5.4 & 70 & 76 & 78 & 85 & 90 & & & & \\
\hline 10 & 1236.1 & 7.0 & 75 & 76 & 85 & 86 & 91 & & & & \\
\hline 11 & 1083.6 & 6.2 & 75 & 79 & 85 & 86 & 90 & 94 & & & \\
\hline 12 & 1107.4 & 6.3 & 74 & 77 & 79 & 86 & & & & & \\
\hline 13 & 1788.6 & 10.2 & 76 & & & & & & & & \\
\hline 14 & 654.8 & 3.7 & 74 & 78 & & & & & & & \\
\hline 15 & 994.8 & 5.7 & 68 & 70 & 72 & 77 & 78 & 82 & 89 & 90 & 94 \\
\hline 16 & 1406.9 & 8.0 & 68 & 71 & 76 & 78 & 79 & 83 & 89 & & \\
\hline 17 & 979.2 & 5.6 & 68 & 70 & 71 & 75 & 76 & 80 & 83 & 89 & 94 \\
\hline 18 & 956.4 & 5.4 & 72 & 73 & 77 & 90 & & & & & \\
\hline 19 & 508.8 & 2.9 & 68 & 75 & 76 & 77 & 86 & 89 & 90 & & \\
\hline 20 & 425.1 & 2.4 & 68 & 75 & 77 & 82 & & & & & \\
\hline 21 & 402.8 & 2.3 & 70 & 71 & 74 & 75 & 76 & 78 & 79 & 89 & \\
\hline 22 & 84.7 & 0.5 & 68 & 72 & 75 & 76 & 79 & & & & \\
\hline 23 & 459.2 & 2.6 & 76 & 77 & 79 & 80 & & & & & \\
\hline 24 & 114.1 & 0.6 & 71 & 78 & 79 & 83 & & & & & \\
\hline 25 & 877.0 & 5.0 & 72 & 73 & 77 & 90 & 91 & & & & \\
\hline Main Pan & 4622.6 & 20.2 & & & & & & & & & \\
\hline Smaller pans & 703.1 & 3.1 & & & & & & & & & \\
\hline All pans together & 5325.7 & 23.2 & & & & & & & & & \\
\hline \multirow{2}{*}{$\begin{array}{l}\text { Etosha minus } \\
\text { all pans }\end{array}$} & & & & & & & & & & & \\
\hline & 17589.3 & 76.8 & & & & & & & & & \\
\hline Total & 22915.0 & 100.0 & & & & & & & & & \\
\hline
\end{tabular}

fires, which are more likely to occur in areas with high fuel loads. This makes planning and preparing for burning easier considering all the other management tasks that need attention.

Burning after September becomes progressively more harmful, especially to the perennial grasses that begin to sprout as the temperature increases after the winter (Trollope et al. 1991). This often takes place before any rains have fallen in Etosha. Burning shortly after early rains is not harmful to perennial grasses (Le Roux 1988), but unpractical because of logistical reasons and because non-graveled roads cannot be driven on when wet. Furthermore, because of the high variability in rainfall between years, spring rains can not be relied on in Etosha.

Another reason to burn in September is to ensure an effective burn. By November or December areas that had a fuel load of $>2000 \mathrm{~kg} / \mathrm{ha}$ in August, when it is decided which areas to burn, may not have enough fuel left for effective burning. This can happen as a result of high game pressure depleting the fuel load, or as a result of early rain- 


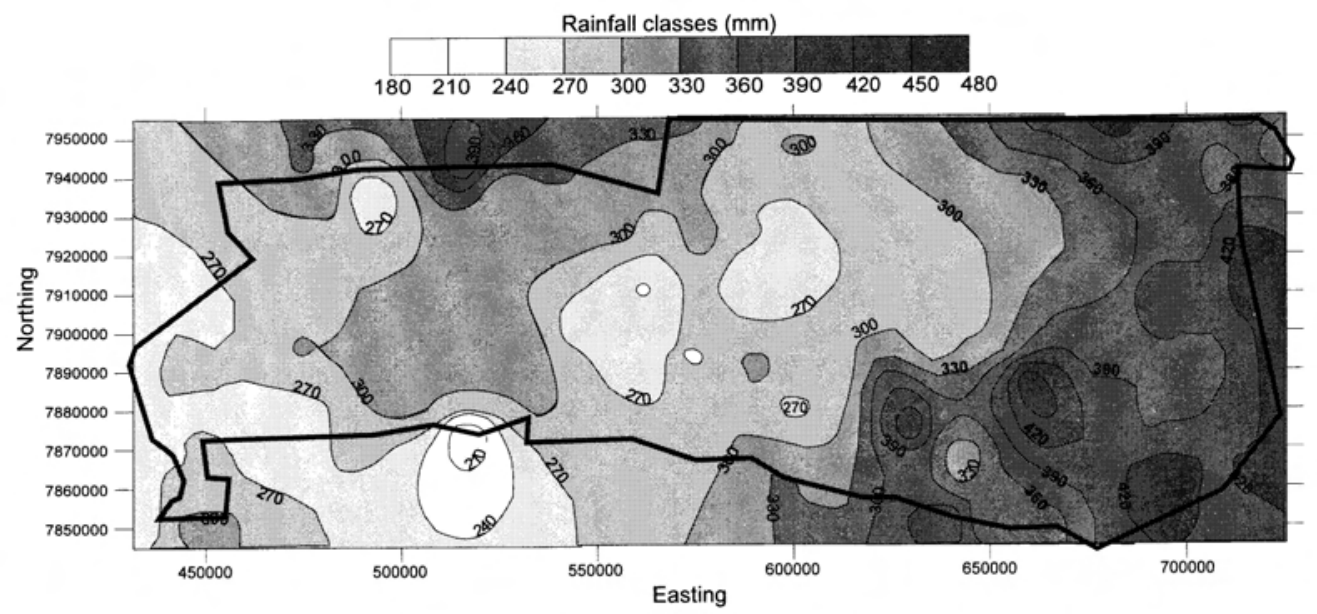

Fig. 10. Rainfall contour map of the Etosha National Park interpolated from field rain gauge means between 1984 and 1995.

fall which can increase decomposition of grasses and reduce the standing crop available as fuel for fires. High temperatures and strong dry winds during these months also reduces the standing crop significantly.

\section{Mean annual rainfall}

No long-term rainfall data was initially available for each block, thus the assumption had to be made that when the mean annual rainfall at any of the five weather stations exceeded the 20 year mean at these stations, it also indicated that the mean annual rainfall of the associated burning blocks (Table 2) exceeded the 20 year mean. A rainfall contour map (Fig. 10) interpolated from point data using the Surfer for Windows software, and examining the mean of rainfall data from 1984 to 1995 confirms that the rainfall data obtained from field rain gauges correlates well with the rainfall patterns observed at the five weather stations in Etosha (Table 2). The east-west gradient in rainfall is apparent.

\section{Percentage of Etosha burnt}

The percentage of Etosha burnt between 1968 and 1995 was determined using both confirmed (map and written information) and unconfirmed (only map information) records. A confirmed minimum and unconfirmed maximum burnt area were therefore obtained. The mean percentage area burnt per year during 1968 to 1995 was $11.0 \%$ using confirmed records and $18.1 \%$ when unconfirmed records are included. As only the confirmed records are reliable to be considered, it strengthened the choice made in 1983 to burn not more than $12 \%$ of Etosha in any year. An area of $12 \%$ is logistically more manageable, and the arid nature of Etosha also favors the recommendation to burn not more than this percentage annually. However, in years with above average rainfall more than $12 \%$ of the park may actually burnt due to lightning fires (Table 3). This is, at the moment, unavoidable because of the logistics of controlling these fires, and is not necessarily undesirable, because it would have happened naturally before fire break roads were constructed in Etosha.

\section{Fire frequency}

The average frequency of all fires in Etosha between 1968 and 1995 range from 5.5 years with unconfirmed records to a more likely figure of 9.1 years using only confirmed records. However, the variation in fire frequency of different blocks are considerable as some blocks like block 13 has only burnt 
once during 28 years (1968 to 1995), and block 15 and 17 have burnt on average every 3.1 years (Table 3 ).

Fig. 11 confirms $(\mathrm{r}=0.9185, d f=11$, $P<0.05)$ that more blocks were burnt either artificially or by lightning in years following above average rainfall (a rainfall mean, taken from all the field rain gauges, of approximately $300 \mathrm{~mm}$ indicates above average rainfall for Etosha).

\section{A structured approach to controlled burning in Etosha}

The ideal fire management strategy for Etosha would be to rely on lightning to set the veld alight. Such fires develop from a point ignition that results in a variety of types and intensities of fires which in turn results in a greater mosaic of effects on the vegetation thereby causing a greater diversity of habitat types.

Another method would be to use patch-burning as it is used in Uluru National Park in Australia (Saxon 1984). Patch-burning or spot-burning refers to the practice of randomly setting the veld alight inside the selected area to burn using people on foot or vehicles. This type of artificial burning strat- egy prevents artificial structural differences forming in vegetation at different sides of burning blocks because of avoiding the same fire intensities or types (head or back fires) during consecutive burning between years.

However, fires caused by lightning or patchburning are currently undesirable because they are difficult to control and to restrict to a given area. Etosha and the areas around are influenced by anthropogenic development and land use practices (rest camps, roads and artificial water holes are present in Etosha and commercial and communal farming areas surround the park). Etosha management is also seriously under-staffed and under-financed which limits quick response to unplanned fires. Consequently, controlled burning along firebreak roads simulating the natural incidence of lightning fires is used as the current preferred management tool in Etosha.

\section{Conclusions}

When 20 years of rainfall data has been obtained from the burning blocks, the annual rainfall of a block can be compared to the 20 year mean of that block, and it is not necessary to compare this to the 20 year mean of the nearest station's rainfall as it is done cur-

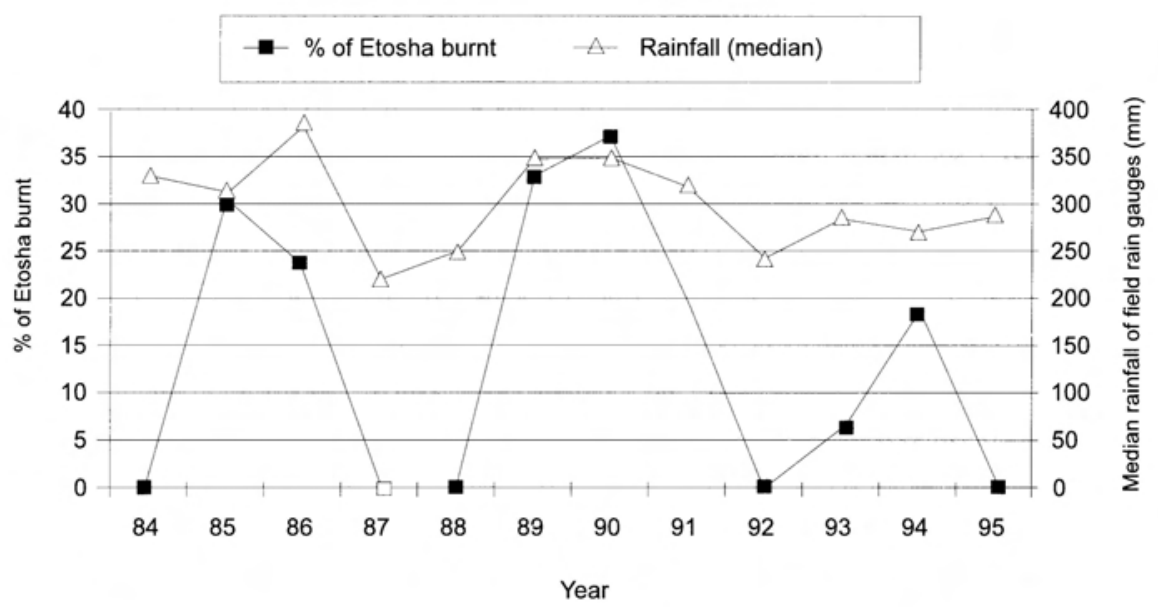

Fig. 11. Relationship between rainfall and percentage of the Etosha National Park burnt between 1984 and 1995 using field rain gauge data. 
rently. This burning strategy provides Etosha management and research staff with an objective set of criteria to determine which areas should burn in a certain year. However, the reality has often been that because of a lack of manpower and resources to investigate or control reported fires, bigger areas are often burnt than planned. Therefore, if after regular monitoring (based on objectively defined criteria) it is found that plant species diversity is declining, and the cause is attributed to the incorrect use of fire, the current burning strategy should be revised.

\section{Acknowledgments}

Dr Pauline Lindeque developed and provided a computer program without which our initial calculations would have been time consuming and laborious. The Ministry of Environment \& Tourism of Namibia is thanked for supporting this ongoing long-term monitoring and research at the Etosha Ecological Institute.

\section{References}

BERRY, H.H. 1980. Behavioural and eco-physiological studies on blue wildebeest Connochaetes taurinus at Etosha National Park. Unpublished Ph.D. thesis, Univ. of Cape Town.

ENGERT, S. 1992. Raumliche variabilitat und zeitliche periodizitat der niederschlage im Etoscha Nationalpark/Namibia: mit einer anmerkung zur erosivitat der niederschlage. Diplomarbeit. Univ. von Regensburg, Deutschland.

GerTENBACH, W.P.D. \& A.L.F. POTGIETER. 1979. Veldbrandnavorsing in die struikmopanieveld van die Nasionale Krugerwildtuin. Koedoe 22: 1-28.

KAnNEnBERG, N. 1992. Grass-Biomasse in Savannenbiomen des Etosha National Park: Anwendung des Disc Pasture Meter (DPM). Pp. 76-91. In: K. WEISS \& J. GOLDAMMER. (Red.). Feuer in der Umwelt. Arbeitsgruppe Feuerökologie und Biomasseverbrennung, MaxPlanck-Institut für Chemie, Albert-LudwigUniversität Freiburg, Germany.

LE ROUX, C.J.G. 1988. Die invloed van brand en maai op onbeweide langgrasveld in Natal. Journal of the Grassland Society of southern Africa 6 (2): 59 - 64.

Le RouX, C.J.G., J.O. Grunow, J.W. MorRIS, G.J. BREDENKAMP \& J.C. SCHEEPERS. 1988. A clas- sification of the vegetation of the Etosha National Park. South African Journal of Botany 54(1): 1 - 10.

LILLESAND, T.M. \& R.W. KIEFER. 1994. Remote sensing and image interpretation. New York: John Wiley.

LINDEQUE, P.M. 1991. Factors affecting the incidence of anthrax in the Etosha National Park, Namibia. Ph.D. thesis. Council for National Academic Awards, UK.

MuElleR-DOMBOIS, D. \& H. ElLENBERG. 1947. Aims and methods of vegetation ecology. New York: John Wiley.

NotT, T.B., M. LindeQue, A. Cilliers, K. VENZKE \& J.L. SCHEEPERS. 1985. Masterplan for the Etosha National Park. Internal report. Ministry of Environment and Tourism, Namibia.

SAXON, E.C. 1984. Anticipating the inevitable: a patch-burning strategy for fire management at Uluru National Park. Melbourne: CSIRO Division of Wildlife and Rangeland Research.

Scholes, R.J. \& B.H. WalkeR. 1993. An African savanna: synthesis of the Nylsvley study. Cambridge: Cambridge University Press.

SIEGFRIED, W.R. 1980. The incidence of veld-fire in Etosha National Park. Madoqua. 12(4): 225-230.

Stander, P.E., T.B. NotT \& M.T. MEnTIS. 1993. Proposed burning strategy for a semi-arid African savanna. African Journal of Ecology. 31: 282-289.

STEPHENSON, J. 1991. NOAA AVHRR receiving and processing system. Bradford Univ. Research Ltd., Natural Resources Institute \& Cranfield Institute of Technology, UK.

Trollope, W.S.W., H.C. Biggs, A.L.F. Potgieter \& N. ZamBATIS. 1996. A structured versus a laissez faire approach to controlled burning in the Kruger National Park in South Africa. Congress 31 of the Journal of the Grassland Society of southern Africa, Nelspruit, South Africa.

Trollope, W.S.W., C.S. Everson \& N.M. TAINTON. 1991. Effect and use of fire in the grassland and savanna areas of south Africa. In: Tainton, N.M. (ed.). Veld and pasture management in South Africa. Pietermaritzburg: Shuter \& Shooter.

Trollope, W.S.W. \& A.L.F. POTGIETER. 1985. Fire behaviour in the Kruger National Park. Journal of the Grassland Society of southern Africa 2(2): 17-22.

Trollope, W.S.W. \& A.L.F. POTGIETER. 1986. Estimating grass fuel loads with a disc pasture meter in the Kruger National Park. Journal of the Grassland Society of southern Africa 3(4): 148-152. 